\title{
PERAN PENDIDIKAN AKUNTANSI DALAM MASYARAKAT
}

\author{
Nur Afni ${ }^{1}$, Abdul Jalil ${ }^{2}$ \\ ${ }^{1}$ Jurusan Akuntansi, Universitas Alkhairaat, UNISA Palu, nur.afni.tadjuddin@gmail.com \\ 2 Jurusan Perbankan, Fakultas Ekonomi dan Bisnis Islam, IAIN Palu, abdul_jaliil@iainpalu.ac.id
}

\section{ABSTRAK}

Akuntansi perlu dipelajari karena seiring dengan perkembangan zaman, tingkat pertumbuhan ekonomi pun berkembang banyak perusahaan jasa maupun perusahaan dagang baru bermunculan, semua perusahaan tersebut pasti membutuhkan laporan keuangan untuk melihat pendapatan dan pengeluaran yang terjadi diperusahaannya. Ilmu akuntansi sudah dapat dipelajari mulai dari tingkat sekolah menengah atas dan tingkat perguruan tinggi. Kualitas pendidikan akuntansi harus mengikuti zaman agar lulusannya menjadi seorang akuntan yang dapat bersaing di dunia kerja dengan baik.pemerintah sudah menujang perkembangan pendidikan melalui kurikulum yang baru, tetapi tetap membutuhkan dukungan serta peran aktif dari berbagai pihak agar perkembangan pendidikan khususnya pendidikan ilmu akuntansi dapat berjalan dengan lancar. Perkembangan pendidikan khususnya pendidikan ilmu akuntansi haruslah diperhatikan karena akuntansi sangat dibutuhkan diberbagai bidang bukan hanya dalam bidang bisnis saja, tidak hanya mengandalkan pemerintah saja tetapi ikut serta dalam pengembangannya, agar kualitas pendidikan ilmu akuntansi dapat mengikuti kemajuan zaman yang sedang terjadi.
INFORMASI

ARTIKEL

\author{
Katakunci: \\ Pendidikan Akuntansi \\ di Masyarakat
}




\section{PENDAHULUAN}

Kita semua tahu, semakin banyak disiplin ilmu di Indonesia khususnya di kalangan perguruan tinggi negeri maupun swasta seperti ilmu social, alam, seni, sastra, psikologi, komunikasi, hingga akuntansi. Semakin berkembangnya jaman, berbagai disiplin ilmu itu dapat saling dikaitkan hingga saling berkesinambungan, walaupun setiap disiplin ilmu memiliki konsentrasi yang beragam dan berbeda-beda. Manusia dalam membangun upaya dalam peningkatan mutu dan martabat hidupnya. Upaya yang paling utama yang dilakukan adalah dengan pendidikan. ${ }^{1}$

Berbagai macam disiplin ilmu, semakin komplekslah disiplin-disiplin ilmu, khususnya disiplin ilmu akuntansi. Akuntansi memiliki peranan yang sangat penting dalam lingkungan ekonomi hingga masyarakat. Hal ini disebabkan adanya permasalahan soal keuangan yang harus mau tidak mau menggunakan ilmu akuntansi sebagai pemecah problematika tersebut. Sehingga membuat akuntansi ini merupakan salah satu ilmu yang digunakan dalam profesi khususnya di bidang organisasi perusahaan ataupun bisnis.

Amin W. Tunggal berpendapat bahwa akuntansi merupakan aktivitas jasa (mengidentifikasikan, mengukur, mengklasifikasikan dan mengikhtisarkan) kejadian atau transaksi ekonomi yang menghasilkan informasi kuantitatif terutama yang bersifat keuangan yang digunakan

\footnotetext{
${ }^{1}$ Hairuddin Cikka, Strategi Komunikasi Guru Memotivasi Peserta Didik Dalam Meningkatkan Prestasi Belajar, Al-mishbah, Vol.15 No. 2 Juli - Desember 2019.
}

dalam pengambilan keputusan. ${ }^{2}$ Ada pula pendapat lain yang mengatakan bahwa akuntansi adalah proses identifikasi, pencatatan dan komunikasi terhadap transaksi ekonomi dari suatu entitas/perusahaan. ${ }^{3}$

Dapat disimpulkan bahwa akuntansi merupakan suatu proses mencatat, meringkas, mengolah, mengklarifikasi dan menyajikan data transaksi dari berbagai kejadian yang berhubungan dengan keuangan. Susunan laporan tersebut sangat berguna untuk manajemen keuangan di periode berikutnya.

Adapun tiga kegiatan utama dalam akuntansi di antaranya:

1. Identifikasi setiap transaksi

2. Pencatatan setiap transaksi secara sitematis sesuai dengan standart yang berlaku

3. Aktivitas komunikasi akuntansi internal maupun eksternal

Di zaman yang semakin berkembang ini, semakin ke sini dunia usaha pun juga ikut berkembang juga. Perkembangan itupun berbagai variasi metodenya. Bahkan jika kita melihat perusahaan bidang jasa dan barang yang dulunya kecil, kini semakin berkembang dan mengalami kemajuan yang pesat. Dulunya yang masih sektor usaha, kini menjadi sektor besar. Hal ini mulai terasa setelah tahun 1980-an yang bersamaan dengan berdirinya BEJ.

${ }^{2}$ Amin W. Tunggal, Akuntansi Perusahaan Kecil dan Menengah (Jakarta: Rineka. Cipta. 1997).

Dalam

https://www.trigonalmedia.com/2016/10/pen gertian-akuntansi-menurut-para-ahli.html, Diakses 26 Desember 2020.

${ }^{3}$ Abubakar, Wibowo. Akuntansi Untuk Bisnis:Usaha Kecil dan Menengah. (Jakarta: PT. Gramedia Widiasarana Indonesia, 2004). Dalam http:/ / repository. unpas. ac. id/ 32911 /5/BAB\%20DUA.pdf, Diakses 26 Desember 2020.

e-ISSN: 2686-6625 
Dengan adanya BEJ, bunga bank yang tinggi membuat berbagai perusahaan untuk menggunakan alternatif ini sebagai pemenuhan kebutuhan modal juga persaingan antar perusahaan yang bersamaan pula dengan berbagai permasalahan antarperusahaan khususnya di Indonesia. Sehingga, membuat banyak para pengelola perusahaan atau pihak manajemen perusahaan yang mulai membutuhkan informasi keuangan atau akuntansi dalam memutuskan keuangan perusahaan di periode berikutnya.

Dalam membahas akuntansi dalam alquran ada dua kemungkinan pengertian yaitu akuntansi yang biasa kita dengar seperti akuntansi konvensioanal dan akuntansi Syariah yang dalam Alquran relevan dengan domain akuntansi dan bukan hanya dalam arti konvensional tetapi dalam berbagai bentuk yang tertetara dalm alquran maupun dari sejarah kebudayaan Islam. ${ }^{4}$

\section{TINJAUAN PUSTAKA}

\subsection{Pengertian Akuntansi}

Akuntasi

pencatatan, penjurnalan dan pembukuan kegiatan ekonomi sehingga menghasilkan suatu laporan keuangan yang dapat diinformasikan kepada pihak yang membutuhkan. "Akuntansi adalah proses mengidentifikasi, mengukur, dan melaporkan informasi ekonomi untuk membuat pertimbangan dan mengambil keputusan yang tepat

${ }^{4}$ Abdul Jalil \& Sitti Azizah Hamzah (2020). Pengaruh Bagi Hasil dan Kebutuhan Modal Terhadap Minat UMKM Mengajukan Pembiayaan pada Lembaga Keuangan Syariah di Kota Palu. Jurnal Ilmu Perbankan dan Keuangan Syariah, 2(2), 178-198. bagi pemakai informasi tersebut. Termasuk keharusan bagi akuntansi." 5

Seperti yang telah disampaikan oleh pendapat diatas akuntansi merupakan suatu proses mencatat dan melaporkan suatu informasi ekonomi kepada yang membutuhkan agar pemakai informasi tersebut dapat mengambil keputusan yang tepat untuk kondisi yang sedang terjadi.

Sementara itu pihak yang memakai informasi tersebut terdiri pihak dari dalam perusahaan seperti direktur dan manajer keuangan suatu perusahaan, serta dari pihak luar seperti investor yang akan menanamkan modalnya diperusahaan tersebut, bank yang akan memberikan pinjaman kredit, dan lembaga pemerintahan juga membutuhkan informasi akuntansi suatu perusahaan untuk tujuan perpajakan. Maka dapat disimpulkan bahwa akuntansi itu sangat penting dalam keberlangsungan suatu perusahaan.

Akuntansi memiliki pedoman dalam menyusun laporan keuangan, yaitu disebut dengan prinsip akuntansi. Penyusunan prinsip akuntansi menjadi tanggung jawab dari organisasi akuntansi, untuk di Indonesia disusun oleh Ikatan Akuntansi Indonesia (IAI). Prinsip akuntansi yang disusun oleh IAI sekarang sudah mengadaptasi dari standar akuntantasi internasional terbaru yang dikeluarkan oleh IASB yaitu IFRS.

Sejalan dengan kemajuan teknologi dan ekonomi menimbulkan berbagai macam spesialisasi dalam akuntansi seperti akuntansi keuangan, akuntansi manajemen, akuntansi biaya, akuntansi pajak, akuntansi

${ }^{5}$ Lili M. Sadeli, Dasar-dasar Akuntansi (Jakarta: Bumi Aksara, 2009), 2. 
pemerintahan, akuntansi sosial, akuntansi internasional dan akuntansi pendidikan. Ada juga auditing yang aktivitasnya berfokus pada suatu pemeriksaan atas catatan-catatan akuntansi. Akuntan yang memberikan jasa pemeriksaan akuntansi ini disebut akuntan publik.

Dalam Al-Quran terdapat banyak ayat yang menjelaskan konsep Muamalah dalam Islam mengenai prinsip akuntansi. Salah satunya adalah Ayat 282 dari Surat Al Baqarah :

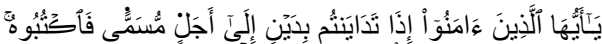

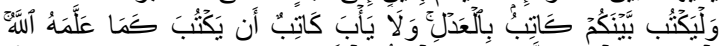

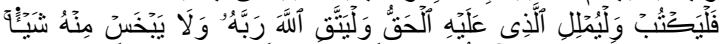

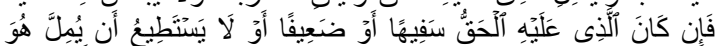

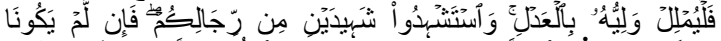

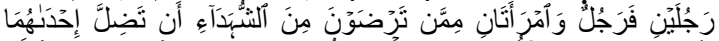

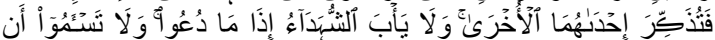

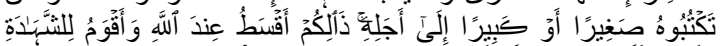

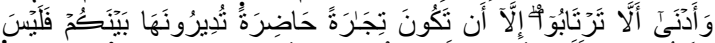

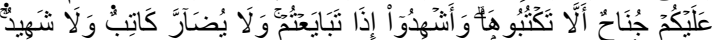

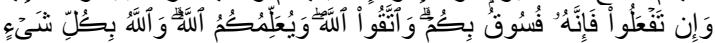
عَليمن

Terjemahannya :

" Hai orang-orang yang beriman, apabila kamu bermu'amalah tidak secara tunai untuk waktu yang ditentukan, hendaklah kamu menuliskannya. dan hendaklah seorang penulis di antara kamu menuliskannya dengan benar. dan janganlah penulis enggan menuliskanny a sebagaimana Allah mengajarkannya, meka hendaklah ia menulis, dan hendaklah orang yang berhutang itu mengimlakkan (apa yang akan ditulis itu), dan hendaklah ia bertakwa kepada Allah Tuhannya, dan janganlah ia mengurangi sedikitpun daripada hutangnya. jika yang berhutang itu orang yang lemah akalnya atau lemah (keadaannya) atau Dia sendiri tidak mampu mengimlakkan, Maka hendaklah walinya mengimlakkan dengan jujur. dan persaksikanlah dengan dua orang saksi dari orangorang lelaki (di antaramu). jika tak ada dua orang lelaki, Maka (boleh) seorang lelaki dan dua orang perempuan dari saksi-saksi yang kamu ridhai, supaya jika seorang lupa Maka yang seorang mengingatkannya. janganlah saksi-saksi itu enggan (memberi keterangan) apabila mereka dipanggil; dan janganlah kamu jemu menulis hutang itu, baik kecil maupun besar sampai batas waktu membayarnya. yang demikian itu, lebih adil di sisi Allah dan lebih menguatkan persaksian dan lebih dekat kepada tidak (menimbulkan) keraguanmu. (Tulislah mu'amalahmu itu), kecuali jika mu'amalah itu perdagangan tunai yang kamu jalankan di antara kamu, Maka tidak ada dosa bagi kamu, (jika) kamu tidak menulisnya. dan persaksikanlah apabila kamu berjual beli; dan janganlah penulis dan saksi saling sulit menyulitkan. jika kamu lakukan (yang demikian), Maka Sesungguhnya hal itu adalah suatu kefasikan pada dirimu. dan bertakwalah kepada Allah; Allah mengajarmu; dan Allah Maha mengetahui segala sesuatu". 6

\subsection{Pengertian Pendidikan}

Pendidikan merupakan sesuatu yang sangat penting karena dapat merubah dunia menjadi lebih baik, dengan pendidikan seseorang bisa mendapat ilmu pengetahuan yang berguna dan dapat meningkatkan kemampuan dirinya sehingga ia bisa menjadi seseorang yang sukses dan berhasil dikehidupannya.

6 Kementrian Agama RI, Syaamil AlQur'an dan Terjemahannya, (Cet I; Bandung: Syaamil Cipta Media, 2005), 
Menurut Bastian pendidikan adalah kunci kemajuan semua bidang. Oleh karenanya, argumentasi pendidikan sebagai hak asasi manusia perlu dikembangkan menjadi pendidikan adalah alat pembangunan sosial dan ekonomi. ${ }^{7}$ Sedangkan menurut Natsir Ali sebagaimana dikutip oleh Taufiq K. dan Cikka Pendidikan dapat diartikan secara sempit yaitu bimbingan yang diberikan kepada anakanak sampai ia dewasa. Sedangkan dalam arti luas adalah segala sesuatu yang menyangkut proses perkembangan dan pengembangan manusia, yaitu upaya menanamkan dan mengembangkan nilai-nilai bagi anak didik, sehingga nilai-nilai yang terkandung dalam pendidikan itu menjadi bagian dari kepribadian anak yang pandai, baik, mampu hidup, berguna bagi masyarakat. ${ }^{8}$

Dari uraian diatas sudah diperjelas bahwa pendidikan itu sangat penting dan dapat menghasilkan kemajuan dalam semua bidang. Karena melalui pendidikan kesempatan seseorang untuk memperoleh ilmu dan keterampilan akan terbuka. Di Indonesia sendiri sudah terdapat dasar hukum tentang penyelenggaraan pendidikan, yaitu :

1. Undang-undang Dasar tahun 1945, yaitu pasal 31 UUD 1945, pasal 1 dan pasal 2.

${ }^{7}$ Bastian I, Akuntansi Pendidikan (Jakarta: Erlangga, 2007). Dalam https:// jurnal konstitusi.mkri. id, Diakses 26 Desember 2020.

8Oyan D. Taufiq K. dan Hairuddin Cikka, Penerapan Pendidikan Dasar Militer (DIKSARMIL) Dalam Membentuk Kepribadian Resimen Mahasiswa Institut Agama Islam Negeri (IAIN) Palu, Moderasi: Jurnal Studi Ilmu Pengetahuan Sosial, Volume 1, No. 1, 110-139, 2020.
2. Pasal (1): Tiap-tiap warga negara berhak mendapat pengajaran.

3. Pasal (2): Pemerintah mengusahakan dan menyelenggarakan suatu sistem pengajaran nasional, yang diatur Undang-undang.

4. Undang-undang No.20 Tahun 2003 tentang Sistem Pendidikan Nasional.

Islam menjunjung tinggi ilmu pengetahuan. Di dalam kitab suci AlQur'an kerap kali ditemukan seruan agar manusia mau berpikir dan mengolah kemampuan akal. Islam juga bisa disebut sebagai agama pendidikan. Sebab, segala ajaran yang terkandung di dalamnya akan mengantarkan manusia untuk beranjak dari kegelapan menuju cahaya yang terang benderang. Dijelaskan dari hadist Riwayat Ahmad yang berbunyi :

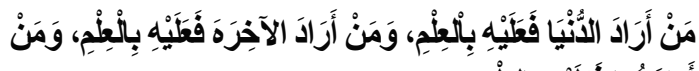

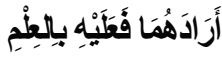

Terjemahannya :

"Barangsiapa yang hendak menginginkan dunia, maka hendaklah ia menguasai ilmu. Barangsiapa menginginkan akhirat, hendaklah ia menguasai ilmu. Dan barang siapa yang menginginkan keduanya (dunia dan akhirat), hendaklah ia menguasai ilmu."

9 https://m.oase.id/read/qW0mVR-10hadis-tentang-pendidikan. Diakses 31 Mei 2021 
2.3 Sistem Pendidikan Akuntansi dan Kurikulum Jurusan Akuntansi di Indonesia

Pendapat bahwa sistem pendidikan tinggi nasional kita belum menghasilkan output yang berkualitas tampaknya merupakan 'penyakit' yang terus mendera dunia pendidikan tinggi. Pendapat yang muncul menilai kualitas lulusan belum mampu bersaing dengan lulusan luar negeri. ${ }^{10}$

Sistem pendidikan di Indonesia secara umum cenderung mengajarkan ilmu bisnis dan akuntansi dengan pendekatan seperti yang digunakan dalam ilmu-ilmu alam. Pengajaran teori dan konsep lebih diarahkan pada proses indoktrinasi dimana mahasiswa harus mampu untuk menguraikannya sesuai dengan pemahaman dari pengarang buku teks (text-book) atau dosen yang mengajarkan. Ketidaksesuaian dengan pemahaman tersebut akan menghasilkan konsekuensi nilai yang tidak menguntungkan bagi mahasiswa yang bersangkutan. ${ }^{11}$

Pandangan miring tentang dunia pendidikan tinggi datang dari berbagai unsur masyarakat yang salah satunya adalah adanya proses belajar mengajar yang cenderung hanya mentransfer ilmu pengetahuan. Akibatnya output yang dihasilkan hanya mengetahui teori saja. Mahasiswa tidak dirangsang untuk

${ }^{10}$ Fakhri, Husein, TI dan Kurikulum Akuntansi di PT. Media Akuntansi, No.35, edisi Juni, 41-44, 1999.

11Sujoko Efferin, Pentingnya Subyektifitas dalam Pendidikan Tinggi Bisnis dan Akuntansi, Media Akuntansi, No. 28/ Th V Agustus, 2-3, 1998. berfikir kritis dan kreatif. Hal ini dapat terjadi karena dalam proses pengajaran tidak disertai dengan proses komunikasi dua arah yang memungkinkan terjadinya dialog. Hal yang sama terjadi pula dengan pendidikan akuntansi. ${ }^{12}$

Teori dan konsep yang diajarkan disadari atau tidak telah diarahkan sebagai suatu kebenaran yang universal, netral dan obyektif. Subyektivitas mahasiswa dalam memahami teori dan konsep menjadi kurang mendapatkan penghargaan. Penggunaan sudut pandang yang berbeda dalam menginterpretasikan dan memahami teori tertentu menjadi sesuatu yang salah. Pendidikan bisnis dan akuntansi menjadi suatu proses yang kaku, mekanistis, dan cenderung menekankan pada memorisasi.

Hal-hal yang dialami oleh mahasiswa selama duduk di bangku perkuliahan membentuk pola berfikir dan cara bersikap mereka setelah memasuki dunia kerja nyata. Lebih lanjut, menyatakan bahwa lulusan fakultas ekonomi (khususnya akuntansi) menjadi kurang kreatif dalam melihat permasalahan dan cenderung menggunakan sudut pandang yang sempit dalam mencari solusinya. Insting kewirausahaan dalam menghadapi permasalahan yang seharusnya sudah terbentuk sejak mahasiswa menjadi baru mulai dibentuk setelah terjun dalam dunia praktek. ${ }^{13}$

Insting merupakan prasyarat yang menentukan seberapa jauh dan

${ }^{12}$ Husein, TI dan Kurikulum, Media Akuntansi, No.35, edisi Juni, 41-44, 1999.

${ }^{13}$ Ibid., 
cepat seorang lulusan mampu untuk beradaptasi dengan dunia nyata. Pembentukan naluri bisnis yang seharusnya menjadi tugas perguruan tinggi selain pengenalan akan teori dan konsep, telah diserahkan pada dunia kerja. Hal ini merupakan tambahan biaya bagi dunia kerja. Lulusan perguruan tinggi memang bukan diarahkan untuk siap pakai, namun dengan kondisi ini bahkan mereka masih jauh dari siap latih. Naluri wirausaha harus dibentuk dulu baru kemudian secara bertahap mereka dilatih. ${ }^{14}$

Suasana dalam pendidikan akuntansi diperparah lagi dengan adanya kesenjangan antara suasana di kelas dan kondisi praktek di dunia profesi. Salah satu yang mendorong terjadinya kesenjangan tersebut adalah perkembangan teknologi yang cepat tanpa diimbangi oleh penguasaan teknologi yang baik. Program link and match pendidikan selama ini dalam implementasinya cenderung memandang bahwa mahasiswa harus mengetahui dunia praktek dengan cara magang. Ilmu pengetahuan paling tidak saat ini lahir dari proses akademik sedangkan akuntansi adalah kebutuhan profesi yang berkembang secara praktek dalam dunia bisnis. Sering terjadi antara hasil proses ilmu pengetahuan dari proses akademik sering tidak match atau Koesbandijah dalam Kholis, mengemukakan pentingnya kualitas pengajaran akuntansi. $^{15}$ Pendapat ini sejalan dengan pendapat Machfoedz, yang

\footnotetext{
${ }^{14}$ Efferin, Pentingnya, 2-3.

${ }^{15}$ Azizul Kholis, Kontribusi PPA terhadap Pengembangan Profesi Akuntan Tantangan Abad 21. Wahana, Vol.2 (1), 31-40.
}

mengatakan bahwa salah satu faktor penting tidak sesuai dengan keinginan atau kebutuhan dunia praktek sehingga terjadi gap antara dunia akademis dengan dunia profesi. ${ }^{16}$

Koesbandijah dalam Kholis, mengemukakan pentingnya kualitas pengajaran akuntansi. ${ }^{17}$ Pendapat ini sejalan dengan pendapat Machfoedz , yang mengatakan bahwa salah satu faktor penting dalam pendidikan akuntansi adalah kualitas atau profesionalisme pengajaran yang menjadi proses transfer ilmu pengetahuan. ${ }^{18}$

Para pakar akuntansi di Indonesia mengemukakan bahwa pengembangan pendidikan akuntansi ini tentunya harus terikat pula dengan perubahan lingkungan yang sangat cepat khususnya di bidang teknologi informatika. ${ }^{19}$ Pendidikan akuntansi selayaknya diarahkan untuk memberi pemahaman konseptual yang didasarkan pada penalaran sehingga ketika kahirnya masuk ke dalam dunia praktek dapat beradaptasi dengan keadaan sebenarnya. ${ }^{20}$

Pendidikan akuntansi terdiri dari tiga komponen yang saling berhubungan yaitu pengajaran, penelitian, dan praktek. Kemampuan

${ }^{16}$ Mas'ud Machfoed, Strategi Pendidikan Akuntansi dalam Era Globalisasi. Perspektif, No. 07/ Edisi Juli-Sept, 64-75, 1997.

17 Kholis, Kontribusi PPA, Vol.2 (1), 3140.

18 Machfoed, Strategi, Perspektif, No. 07/ Edisi Juli-Sept, 64-75, 1997.

19 Husein, TI dan Kurikulum, Media Akuntansi, No.35, Edisi Juni, 41-44, 1999.

20Syukry Abdullah, dan Selamat Syukur, "Persepsi Mahasiswa Akuntansi terhadap Profesi Akuntansi Publik: Sebuah Studi Empiris". Media Riset Akuntansi, Auditing, dan Informasi, Vol. 2 (1), 66-90. 2002. 
untuk mengimplementasikan perubahan dalam pendidikan akuntansi membutuhkan pengetahuan akan faktor-faktor yang mempengaruhi pendidikan akuntansi, yang salah satunya adalah pasar tenaga kerja, karena proses pendidikan adalah bagian dari lingkungan persaingan. Kenyataan yang terjadi adalah banyaknya keluhan yang ditemukan di pasar kerja bahwa apa yang diajarkan di bangku kuliah tidak relevan dengan apa yang diinginkan dengan pasar atau user dari tenaga akuntan Kurikulum pendidikan akuntansi di Indonesia dianggap kurang sensitif terhadap permintaan pasar. Kurikulum justru terbebani dengan berbagai yang dihasilkan perguruan tinggi itu. Jika hal ini berjalan terus maka akuntansi juga akan mengalami krisis. ${ }^{21}$

Kurikulum pendidikan akuntansi di Indonesia dianggap kurang sensitif terhadap permintaan pasar. Kurikulum justru terbebani dengan berbagai mata kuliah yang kurang bisa memberikan dukungan terhadap arah pendidikan akuntansi. ${ }^{22}$ Oleh karena itu, untuk mempersiapkan sumber daya manusia di bidang akuntansi yang sesuai dengan kondisi dunia usaha di abad ke-21 'proses produksi' di dunia pendidikan juga harus dipersiapkan dengan sebaikbaiknya. Proses produksi di dunia pendidikan tercermin dalam kurikulum yang dijalankannya. ${ }^{23}$

${ }^{21}$ Sofyan Syafri Harahap, Krisis Akuntansi dan Masa Depan Profesi. Media Indonesia. Media Akuntansi, Edisi Des, 55-62, 2003.

${ }^{22}$ Fauzi, Kesiapan Kurikulum Akuntansi sebagai Antisipasi Perubahan Peran Akuntan Manajemen. Media Akuntansi, Februari, 62-65, 2002.

${ }^{23}$ Ibid.
Kemajuan pendidikan di Indonesia tentu saja dapat merubah negara kearah yang lebih baik lagi, begitu pula dengan kemajuan pendidikan ilmu akuntansi di Indonesia sangat berpengaruh kepada kemajuan negara apalagi saat ini sudah memasuki era globalisasi. Di Indonesia sendiri pendidikan ilmu akuntansi sudah dimulai dari tingkat sekolah menengah atas yang bersifat umum maupun yang kejuruan, untuk SMK dengan jurusan akuntansi sudah banyak berdiri di Indonesia, tentu saja jurusan akuntansi SMK mendidik dan melatih siswa-siswi dengan mendalam tentang ilmu akuntansi sehingga ketika lulus bukan hanya bisa melanjutkan ke tingakat perguruan tinggi namun sudah siap di dunia kerja. Berbeda di SMA pelajaran akuntansi baru dipelajari di kelas XI, itu pun hanya bagi siswa yang memilih masuk ke jurusan IPS, ilmu akuntansi yang dipelajari pun tidak sedalam di SMK, karena disesuaikan dengan kurikulum yang diberlakukan oleh pemerintah. Tahun 2013 ini pemerintah telah mengeluarkan kurikulum baru untuk menggantikan kurikulum KTSP yang sebelumnya berlaku, kurikulum 2013 ini diharapkan dapat meningkatkan kualitas pendidikan di Indonesia. Meskipun kualitas pendidikan tidak akan berubah jika tidak ada kemajuan dari pihak tenaga pengajar dan juga kelengkapan sarana prasarana.

"Selain itu juga melalui kurikulum 2013 pemerintah ingin meningkatkan kualitas guru dalam melaksanakan pembelajaran. Guru yang melaksanakan kurikulum 2013 ini harus benar-benar cerdas, aktif, kreatif dan inovatif. Namun yang perlu mendapat sorotan lebih tajam adalah dari sisi pelatihan terhadap guru-gurunya. Apabila kurikulum 2013 ini ingin berjalan secara baik, maka 
perlu dilakukan pelatihan pada tenaga pengajarnya dan perangkat lain yang terlibat karena ia merupakan suatu sistem (mata rantai)." 24

Untuk tingkat perguruan tinggi sudah hampir seluruhnya memiliki progam studi akuntasi dengan kualitas yang berbeda-beda sesuai dengan akreditasnya masing-masing, bahkan setiap tahunnya progam akuntansi banyak diminati oleh para calon mahasiswa baru yang akan masuk ke perguruan tinggi, sehingga meminbulkan persaingan yang ketat.

\section{METHODOLOGY}

Dalam penulisan karya ilmiah ini, penulis menggunakan metode pendekatan penelitian deskripsi kualitatif, 25 yaitu memaparkan aspekaspek yang menjadi sasaran penelitian penulis. Pendekatan yang dimaksud yaitu suatu penelitian yang berusaha untuk menuturkan pemecahan masalah yang ada sekarang berdasarkan datadata, sehingga penulis dapat menemukan kepastian dan keaslian data untuk diuraikan sebagai hasil penelitian yang akurat. ${ }^{26}$ Penelitian yang bersifat

${ }^{24}$ Liana, R. (2013, Juli 28). Kualitas Pendidikan Indonesia. dari ristiliana.blogspot.com: http://ristiliana.blogspot.com/2013/07/analisa-

kurikulum-2013-pada-mata.html, Diakses 26 Desember 2020

25 Nurdin, N. (2018). Institutional Arrangements in E-Government Implementation and Use: A Case Study From Indonesian Local Government. International Journal of Electronic Government Research (IJEGR), 14(2), 44-63. doi: 10.4018/ijegr.2018040104

26 Evita, E., Syahid, A., \& Nurdin, N. (2019). Understanding Students' Learning Outcomes Differences Through the Application of the Market Place Activity Type of Cooperative Learning Model and the Application of Conventional Learning Models International Journal of Contemporary Islamic Education, 1(1), 6785. deskriptif menurut Suharsimi Arikunto "lebih tetap apabila menggunakan pendekatan kualitatif". ${ }^{27,28}$

Adapun yang menjadi objek atau sasaran lokasi penelitian adalah Masyarakat yang ada di Kota Palu. Ini menunjukan bawah lokasi penelitian di anggap sangat representatif terhadap judul penelitian yang diangkat penulis, karena disamping objek dianggap tepat, juga memberikan nuansa baru bagi penelitian dalam menambang pengalaman penelitian, khususnya Pendidikan Akuntansi.

Data dikumpul melalui observasi, wawancara mendalam, dan dari berbagai dokumen yang ada. ${ }^{29}$ Dalam wawancara peneliti melakukan wawancara langsung dengan masyarakat yang dapat memberikan data yang menyakut masalah atau objek penelitian.

\section{HASIL DAN PEMBAHASAN}

\subsection{Ilmu Akuntansi Perlu Dipelajari}

Alasan kenapa akuntansi perlu dipelajari karena seiring perkembangan zaman, tingkat pertumbuhan ekonomi pun berkembang banyak perusahaan jasa maupun perusahaan dagang baru

${ }^{27}$ Suharsimi Arikunto, Prosedur Penelitian Ilmiah, Suatu Pendekatan Praktek,Ed. II, (Cet. IX ; Jakarta : Rineka Cipta, 1993)h 209;

28 Nurdin, N., Stockdale, R., \& Scheepers, H. (2014b, 6-9 Jan. 2014). The Role of Social Actors in the Sustainability of EGovernment Implementation and Use: Experience from Indonesian Regencies. System Sciences (HICSS), 2014 47th Hawaii International Conference on System Science,

29 Nurdin, N., Stockdale, R., \& Scheepers, H. (2014). Coordination and Cooperation in E-Government: An Indonesian Local E-Government Case The Electronic Journal of Information Systems in developing Countries, 61(3), 1-21. 
bermunculan, baik itu perusahaan besar atau perusahaan kecil menengah pasti membutuhkan laporan keuangan untuk melihat pendapatan dan pengeluaran yang terjadi diperusahaannya. menyusunan laporan keuangan bukanlah hal yang mudah dibutuhkan ketelitian, kejujuran dan pengetahuan bagaimana teknik pencatatan kegiatan ekonomi yang baik, itu semua dapat diketahui dengan mempelajari akuntansi. Selain itu akuntansi diperlukan hampir disemua bidang tidak hanya dibidang bisnis saja, seperti sektor pemerintahan juga membutuhkan informasi akuntansi untuk mengetahui arus kas negara, perpajakan, hutang negara, dan masalah ekonomi lainnya. Untuk sektor pendidikan memperlukan informasi akuntansi agar dapat menentukan prioritas dalam pembangunan perlengkapan sarana pendidikan, bahkan dalam kehidupan sehari-hari juga membutuhkan catatan keuangan agar terhindar dari keborosan, maka akuntansi itu perlu dipelajari.

Seperti yang sudah dijelaskan sebelumnya bahwa akuntansi itu banyak dibutuhkan diberbagai bidang, peminat untuk menjadi seorang akuntan pun meningkat, sehingga persaingan untuk masuk progam studi akuntansi di perguruan tinggi menjadi meningkat, bukan hanya itu tetapi ketika sudah lulus pun persaingan di dunia kerja semakin ketat, maka setiap akuntan harus memiliki kualitas, kinerja dan profesional dalam berkerja, bukan hanya mengerti ilmu akuntansi dengan baik saja tetapi memiliki sikap dan moral yang baik juga, sehingga dapat unggul dari akuntan lainnya didalam dunia kerja. Oleh karena itu seorang akuntan harus mempersiapkan dirinya untuk menjadi akuntan yang baik sedini mungkin, salah satunya dengan menempuh pendidikan dengan baik.

\subsection{Mengembangkan Pendidikan Akuntansi \\ Pendidikan ilmu akuntansi yang} baik akan menghasilkan akuntan yang baik juga, sarana untuk mempelajari akuntansi sudah mudah ditemui mulai dari tingkat sekolah atas sampai tingkat perguruan tinggi, namun kualitasnya harus berkembang mengikuti perkembangan zaman yang terjadi. Pemerintah sudah menjalankan tugasnya mengembangkan pendidikan dengan mengeluarkan kurikulum baru yang lebih baik dari sebelumnya, tetapi dengan berlakunya kurikulum baru selalu ada kendala yang muncul sehingga menghambat kurikulum tersebut berjalan dengan baik, seperti pihak pengajar tidak menyetujui kurikulum yang ditawarkan dan sedikitnya buku penunjang kurikulum. Maka perlu dilakukan dukungan serta peran aktif dari berbagai pihak agar pendidikan khususnya pendidikan ilmu akuntansi dapat berkembang dengan baik, seperti tersedianya tenaga pengajar yang berkualitas baik, efektivitas pengembangan pihak pengajar, tercukupinya buku-buku penunjang pendidikan yang berkualitas baik, beserta fasilitas lain yang memadai dan juga manajemen dari pihak sekolah atau perguruan tinggi yang baik sehingga dapat menjalankan sistem belajar mengajar dengan sempurna.

Selain itu dengan memanfaatkan kemajuan teknologi dalam proses belajar dapat diberlakukan, sehingga peserta didik tidak hanya belajar secara teori saja melainkan belajar praktek langsung melalui aplikasi komputer, tentu ini akan memberikan kemampuan lebih kepada peserta didik dalam mengaplikasikan akuntansi kedalam 
teknologi yang ada dan dapat mengikuti kemajuan zaman dengan baik.

\subsection{Manfaat Akuntansi}

4.3.1 Manfaat Akuntansi Bagi Pemilik Saham dan Investor

Pemilik saham adalah orang yang memberikan modalnya digunakan untuk menjalankan kinerja suatu perusahaan. Informasi akuntansi diperlukan oleh pemilik saham untuk menentukan apakah dia akan tetap ataupun tidak memberikan sahamnya. ${ }^{30}$ Dengan informasi akuntansi yang tepat, maka pemilik saham dapat menentukan tindakan yang sesuai. Sehingga pemilik saham tidak akan merugi atau tetap untung. Dengan kata lain, informasi akuntansi berperan dalam menentukan apakah pemilik saham tetap untung yang berarti tetap sejahtera, atau rugi yang berarti kesejahteraannya menurun.

Investor adalah orang yang akan menamkan modalnya untuk kelangsungan suatu perusahaan. Informasi akuntansi bagi investor dan pemilik mempunyai kegunaan yang sama. Dengan informasi yang tepat, maka investor akan dapat menentukan kebijakan yang sesuai. Dengan kebjikan ini, maka investor akan menentukan apakah tetap untung atau sejahtera ataupun merugi atau kesejahteraan berkurang. ${ }^{31}$

Seorang investor dan pemilik saham merupakan masyarakat dengan

30 Nurdin, N., Musyawarah, I., Nurfitriani, N., \& Jalil, A. (2020). Pengaruh Pelayanan Mobile Banking Terhadap Kepuasan Nasabah (Studi Pada Mahasiswa Perbankan Syariah IAIN Palu) Jurnal Ilmu Perbankan dan Keuangan Syariah, 2(2), 87-104.

${ }^{31}$ https://www.kompasiana.com/blankstate/5 4f4125a7455137c2b6c85d5/peran-akuntansi-dalammayarakat, Diakses 26 Desember 2020 pendapatan yang lebih dari cukup. Biasanya, mereka juga memiliki karyawan yang berasal dari masyarakat pendapatan rendah. Apabila mereka merugi, pastinya juga akan berimbas pada karyawan yang berasal dari masyarakat pendapatan rendah yang dapat mengganggu kesejahteraan masyarakat berpendapatan rendah.

\subsubsection{Manfaat Akuntasi Bagi Pemerintah}

Informasi akuntansi diperlukan pemerintah untuk membuat kebijakan yang tepat terhadap suatu perusahaan. Terdapat dua kebijakan yang akan ditentukan oleh pemerintah bagi suatu perusahaan. Kebijakan itu adalah pemberian pajak dan subsidi.

Dengan informasi akuntansi yang tepat, maka pemerintah dapat menentukan pajak yang sesuai dengan kemampuan perusahaan. ${ }^{32}$ Hal ini nantinya, akan mempengaruhi jumlah pajak yang diterima pemerintah yang digunakan untuk kepentingan masyarakat. Sehingga tercipta kesejahteraan yang merata di masyarakat Indonesia.

Dengan informasi akuntansi yang tepat, maka pemerintah dapat menentukan apakah suatu perusahaan mampu untuk berjalan tanpa adanya subsidi pemerintah. Sehingga, anggaran pemerintah akan efisien dan efektif untuk keperluan yang lain. Dengan kata lain, subsidi tidak hanya digunakan untuk membantu perusahaan saja, tetapi dapat digunakan untuk meningkatkan kesejahteraan masyarakat dengan cara

32 Nurdin, N., Azizah, W. N., \& Rusli, R. (2020). Pengaruh Pengetahuan,Kemudahan dan Risiko Terhadap Minat Bertransaksi Menggunakan Finansial Technology (Fintech) Pada Mahasiswa Institut Agama Islam Negeri (IAIN) Palu Jurnal Ilmu Perbankan dan Keuangan Syariah, 2(2), 199-222. 
mengalokasikannya dalam bidang pendidikan maupun kesehatan. ${ }^{33}$

\subsubsection{Manfaat Akuntasi Bagi Manajer dan Karyawan}

Bagi seorang manajer, informasi akuntansi diperlukan untuk mengevaluasi kemajuan perusahaan yang telah dicapai dan melakukan koreksi yang diperlukan. Sehingga, manajer dapat menentukan kebijakan yang tepat untuk memajukan perusahaan. Dengan majunya perusahaan, maka seluruh elemen perusahaan akan dapat meningkat kesejahteraannya.

Seorang karyawan perlu mengetahui bagaimana kondisi dan informasi perusahaan pada saat tertentu. Informasi dan kondisi perusahaan pada saat tertentu dapat diketahui dalam informasi akuntansi. Dengan mengetahui informasi dan kondisi perusahaan, maka seorang karyawan dapat merencanakan langkah yang tepat dalam bekerja. Pada kondisi yang baik, maka seorang karyawan dapat bernafas lega. Akan tetapi, pada kondisi perusahaan yang buruk, maka seorang karyawan harus siap untuk mencari pekerjaan yang lain atau mencari sumber

\section{KESIMPULAN DAN SARAN}

Akuntansi perlu dipelajari karena seiring dengan perkembangan zaman, tingkat pertumbuhan ekonomi pun berkembang banyak perusahaan jasa maupun perusahaan dagang baru bermunculan, semua perusahaan tersebut pasti membutuhkan laporan keuangan untuk melihat pendapatan dan pengeluaran yang terjadi diperusahaannya.

Ilmu akuntansi sudah dapat dipelajari mulai dari tingkat sekolah menengah atas dan tingkat perguruan tinggi. Kualitas pendidikan akuntansi harus mengikuti zaman agar lulusannya menjadi seorang akuntan yang dapat bersaing di dunia kerja dengan baik.pemerintah sudah menujang perkembangan pendidikan melalui kurikulum yang baru, tetapi tetap membutuhkan dukungan serta peran aktif dari berbagai pihak agar perkembangan pendidikan khususnya pendidikan ilmu akuntansi dapat berjalan dengan lancar.

Perkembangan pendidikan khususnya pendidikan ilmu akuntansi haruslah diperhatikan karena akuntansi sangat dibutuhkan diberbagai bidang bukan hanya dalam bidang bisnis saja, tidak hanya mengandalkan pemerintah saja tetapi ikut serta dalam pengembangannya, agar kualitas pendidikan ilmu akuntansi dapat mengikuti kemajuan zaman yang sedang terjadi.

Dari analisis diatas dapat disimpulkan bahwa akuntansi, terutama informasi akuntansi sangat berperan untuk menjaga ataupun meningkatkan kesejahteraan masyarakat.

1. Bagi seorang pemilik saham dan investor adalah untuk menentukan apakah modalnya tepat atau tidak untuk diberikan pada perusahaan.

2. Bagi pemerintah adalah untuk efisiensi anggaran. Sehingga anggaran dapat digunakan untuk kepentingan masyarakat banyak, tidak hanya untuk perusahaan saja.

3. Bagi manajer adalah untuk meentukan kebijakan yang tepat sehingga perusahaan dapat lebih 
maju dan elemen perusahaan lebih sejahtera.

4. Bagi seorang karyawan adalah untuk menyiapkan diri pada saat kondisi perusahaan sedang memburuk sehingga kesejahteraannya tetap stabil

\section{DAFTAR PUSTAKA}

Abdullah, Syukry dan Syukur Selamat, "Persepsi Mahasiswa Akuntansi terhadap Profesi Akuntansi Publik: Sebuah Studi Empiris". Media Riset Akuntansi, Auditing, dan Informasi, vol.2 (1), 66-90. 2002.

Abubakar, Wibowo. Akuntansi Untuk Bisnis:Usaha Kecil dan Menengah. Jakarta. PT. Gramedia Widiasarana Indonesia, 2004.

Amin, $W$ Tunggal. Akuntansi Perusahaan Kecil dan Menengah. Rineka. Cipta. Jakarta, 1997.

Bastian, I. Akuntansi Pendidikan. Jakarta: Erlangga, 2007.

Cikka, Hairuddin. Strategi Komunikasi Guru Memotivasi Peserta Didik Dalam Meningkatkan Prestasi Belajar, Al-mishbah, Vol.15 No. 2 Juli - Desember 2019.

Evita, E., Syahid, A., \& Nurdin, N. (2019). Understanding Students' Learning Outcomes Differences Through the Application of the Market Place Activity Type of Cooperative Learning Model and the Application of Conventional Learning Models International
Journal of Contemporary Islamic Education, 1(1), 67-85.

Efferin, Sujoko. Pentingnya Subyektifitas dalam Pendidikan Tinggi Bisnis dan Akuntansi, Media Akuntansi, no. 28/ Th V Agustus, 2-3, 1998.

Fauzi, Kesiapan Kurikulum Akuntansi sebagai Antisipasi Perubahan Peran Akuntan Manajemen. Media Akuntansi, Februari, 62-65, 2002.

Harahap, Sofyan Syafri. Krisis Akuntansi dan Masa Depan Profesi. Media Indonesia. Media Akuntansi, edisi Des, 55-62, 2003.

https://www.kompasiana.com/blankst ate/54f4125a7455137c2b6c85d5/p eran- akuntansi-dalammayarakat, Diakses 26 Desember 2020

https://m.oase.id/read/qW0mVR-10hadis-tentang-pendidikan. Diakses 31 Mei 2021

Husein, Fakhri. TI dan Kurikulum Akuntansi di PT. Media Akuntansi, No.35, edisi Juni, 41-44, 1999.

Jalil, A., \& Hamzah, S. A. (2020). PENGARUH BAGI HASIL DAN KEBUTUHAN MODAL TERHADAP MINAT UMKM MENGAJUKAN PEMBIAYAAN PADA LEMBAGA KEUANGAN SYARIAH DI KOTA PALU. Jurnal Ilmu Perbankan dan Keuangan Syariah, 2(2), 178-198.

Kholis, Azizul. Kontribusi PPA terhadap Pengembangan Profesi Akuntan Tantangan Abad 21. Wahana, vol.2 (1), 31-40. 
Liana, R. (2013, Juli 28). Kualitas Pendidikan Indonesia. dari ristiliana.blogspot.com: http://ristiliana.blogspot.com/2013/07 /analisa- kurikulum-2013-pada$\underline{\text { mata.html, Diakses } 26 \text { Desember }}$ 2020

Machfoed, Mas'ud. Strategi Pendidikan Akuntansi dalam Era Globalisasi. Perspektif, no. 07/ edisi Juli-Sept, 64-75, 1997.

Nurdin, N., Musyawarah, I., Nurfitriani, N., \& Jalil, A. (2020). Pengaruh Pelayanan Mobile Banking Terhadap Kepuasan Nasabah (Studi Pada Mahasiswa Perbankan Syariah IAIN Palu) Jurnal Ilmu Perbankan dan Keuangan Syariah, 2(2), 87-104.

Nurdin, N., Azizah, W. N., \& Rusli, R. (2020). Pengaruh Pengetahuan,Kemudahan dan Risiko Terhadap Minat Bertransaksi Menggunakan Finansial Technology (Fintech) Pada Mahasiswa Institut Agama Islam Negeri (IAIN) Palu Jurnal Ilmu Perbankan dan Keuangan Syariah, 2(2), 199-222.

Nurdin, N. (2018). Institutional Arrangements in E-Government Implementation and Use: A Case Study From Indonesian Local Government. International Journal of Electronic Government Research (IJEGR), 14(2), 44-63. doi: 10.4018/ijegr.2018040104

Nurdin, N., Stockdale, R., \& Scheepers, H. (2014b, 6-9 Jan. 2014). The Role of Social Actors in the Sustainability of E-Government
Implementation and Use: Experience from Indonesian Regencies. System Sciences (HICSS), 2014 47th Hawaii International Conference on System Science

Nurdin, N., Stockdale, R., \& Scheepers, H. (2014). Coordination and Cooperation in E-Government: An Indonesian Local EGovernment Case The Electronic Journal of Information Systems in developing Countries, 61(3), 1-21.

Sadeli, Lili M. Dsar-dasar Akuntansi. Jakarta: Bumi Aksara, 2009.

Taufiq K. Oyan D. dan Cikka, Hairuddin. Penerapan Pendidikan Dasar Militer (DIKSARMIL) Dalam Membentuk Kepribadian Resimen Mahasiswa Institut Agama Islam Negeri (IAIN) Palu, Moderasi: Jurnal Studi Ilmu Pengetahuan Sosial, Volume 1, No. 1, h. 110-139, 2020. 